\title{
NUEVOS ESCENARIOS EDUCATIVOS PARA UN NUEVO SIGLO
}

\section{NEW EDUCATIONAL SCENARIOS FOR A NEW CENTURY}

RESUMEN Partimos advirtiendo que las transiciones entre siglos aceleran revoluciones en todos los campos, incidiendo especialment en la educarion. La historia registra los avantes pedagoglcos, estos acaban traslacandose a la enseñanza pública y finalmente a las construcciones escolares. La investigación de estos hechos se producce casi con cien anos de demora. Las útilas nuevas inquietudes de progreso para seguir avanzando, incidiendo en los nuevos programas educativos $y$ sus correspondientes escenarios arouitectónicos. La convocatoria buscaba provocar nuevas contribuciones para sintetizar el conocimiento acumulado. La editorial agradece todas las aportaciones que se han producido para esta oportunidad, dejando abiertos nuevos retos interactivos

PaLA el futuro.

SUMMARY We start by observing that the transitions between centuries accelerate revolutions in all fields, especially those affecting education. History records the pedagogical advances, which moved towards public education, and finally, to the construction of schools. Research into these events was delayed by almost one hundred years. The useful critical reflections on these would be published at the end of the 20th century and first years of the 21st, and would be combined with new concerns for progress to conto bring about fresh contributions to compound the accumulated knowledge. The edititor is gratefful for all the contributions that have KEYWORDS education; future; challenges; school architecture; interactions; pedagos.

Persona de contacto / Corresponding author: rabajas@us.es. Escuela Técnica Superior de Arquitectura.Universidad de Sevilla.

os periodos de transiciôn entre siglos suelen estar sembrados de inquietudes y efervescenclas en la bisqueda de huevos paradigmas para revolucionar el progreso. Las cuestiones sobre la contemporanidad y los proyectos para una sociedad futura, activan revisiones sobre los modelos edcellusylos edifios pesc arquitectura, suscitando un gran interes. Los muchos articulos que han concurrido a esta convocatoria confirman que es momento de innovar.

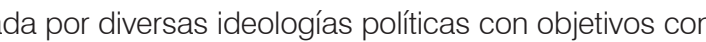
trapuestos, explota truncando el progreso social. El caos y la incertidumbre en que ha derivado de siglo XX, nos obligan a volver al origen, revisar los metodos clasicos, ensayary debatir otros nuevos

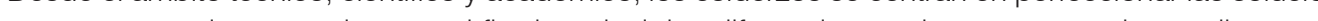
nes para que sirvan a todos con el fin de reducir las diferencias; pedagogos y arquitectos llevamos décadas trabajando en ello, en algunos casos como el de Hertzberger, estrechamente coordinados Los arquitectos pensamos que la arquitectura tiene un papel muy importante en la vida y mucho por hacer. Ahora, un mundo globalizado y entermo tene como priondad regenerar la naturaleza mediante intervenciones que consuman muy pocos recursos. Coherentemente, la ensenanza primarla debe educar en los valores y actitudes civicas que la sociedad necesita y formar en habilidades basicas da a nivel individual y coloctivo, pero qu en cadámbito una Anction

ectura y educación tienen gran relación; así se entendió en los años clave para el establecinino y consolidación de la enseñanza obligatoria y nacieron ejemplos trascendentales, algunos

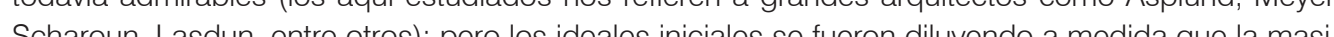
ficación obliǵ a simplificar las intensas experiencias pioneras. Los hechos inclinan a pensar que abandono de a inensidad en la arquitectura es una de las pincipales causas de desprestigio de las instituciones, iniciando un proceso degenerativo; se concluye que resulta esencial insistir desde las 
Leyendo los artículos aquí congregados, nos reencontraremos con las cuestiones que motivaron los primeros pasos de muchos arquilectos hacia la investigación. Alegra comprobar cuánto han evolucionado los medios al servicio de los investigadores: cada dia mas archivos y bibliotecas son accesibles telemáticamente, redes, bases de datos y sistemas abiertos favorecen un conocimiento más agil y contrastable, innumerables publicaciones sobre historia de la educación, la pedagogia y multitud de estudios y tesis sobre construcciones escolares, listados al instante por los polentisimos motores de busqueda... Todo deberá repercutir en la calidad y nitidez de los resultados de investigación. El numero de aportaciones en todos los ambitos ha aumentado tanto que empieza a resultar urgente cierta crítica y cierta síntesis.

Las realizaciones pioneras del XIX evolucionaron en el siglo XX en paralelo al desarrollo histórico de la modernidad: los manifiestos iniciales del primer tercio de siglo, su revisión y normalización tras la Segunda Guerra Mundial, la crisis de la decada de los 70, la postmodernidad... Sucesivamente los modelos van perdiendo intensidad a medida que se reducen las oportunidades para experimentar, sumidos en rutinas normalizadas de aplicación general. Todo movimiento tiene un origen optimista, impulso entusiasta, momento álgido y declive. Deprimidos por la negligencia, muchos volvimos a mirar al pasado para reconocer que estábamos descuidando la calidad en algo tan primordial como el espacio educativo; así en los años ochenta, se emprendieron muchas investigaciones sobre arquilectura escolar que empezaron a difundirse a finales en los noventa y primeros años del presente siglo XXI y todavía se siguen sumando nuevas aportaciones. Aún cuando en muchos casos resulten reiterativas, anima encontrar nuevos estudios que apoyan y refuerzan recurrentemente las mismas conclusiones que olros coeláneos o precedentes, y aún más anima encontrar resultados complementarios que se perfilan como novedosos, concluyentes verdaderamente propositivos. Reconocido el tiempo invertido por la comunidad cientifica y tanto conocimiento acumulado en arquitectura educativa, los experimentos regidos sólo por la intuición y las publicaciones que divulgan imágenes frivolas, descontextualizadas y desprovistas de reflexion y razonamiento, resultan casi siempre decepcionantes, En En la práclica, se aprecian carencias en la traslación transversal de conocimientos entre diferentes campos disciplinares. concrelamente en arquilectura escolar se observa un abismo entre pedagogla arquitectura. Ahora, Io importante para avanzar no es competir, sino colaborar, sin embargo, en

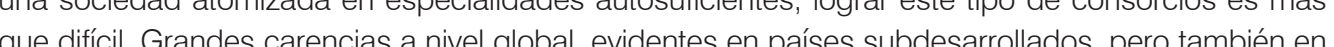
los más desarrollados, donde los dirientes políticos no cesan de reclamar nuevas refornas de los

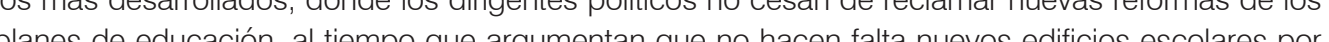
lo índices negativos de crecimiento de la población y la cantidad de escuelas viejas y grandes que se van quedando vacís.

(n) presesvando y mostrando con os centenarios de relevantes instituciones de enseñanza en todo el mundo han propiciado multitud

de estudios sobre del patrimonio educativo. La historia muestra que no todos los elementos que fueron formando la red los años, incluso los más emblemáticos han caído en la obsolescencia perdiendo su brillo inicial. Esta realidad afecta incluso a ámbitos que tenemos idealizados como Franciay Alemania, según afirma en su artículo Anne-Marie Châtelet, prestigiosa investigadora y profesora de Historia de la Arquitectura en varias universidades europeas, cuyas publicaciones en arquitectura escolar son de obligada referencia. Digna invilada a la sección entre lineas, el articulo que nos regala, ejemplar y conciso, compar los modelos francés y alemán en el origen de la enseñanza obligatoria, abordando el caso particular de Estrasburgo, ciudad fronteriza que a lo largo de su historia ha alternado su pertenencia a ambos países, por lo que su estudio aún siendo muy concreto resulta revelador.

El momento actual puede parecer poco afortunado, ensombrecido por guerras y catástrofes derivadas de la sociedad evolucionada en base a esa educación que promocionó la cultura científicotecnológica muy eficiente, pero tambien nociva cuando sivve a una sociedad consumista y deshumanizada. El problema para la arquitectura y la educación empieza a ser grave y seguramente por eso a nivel global, multitud de instituciones locales están abordando la labor de recuperar y divulgar e patrimonio educativo olvidado, indagando insistentemente en el pasado para aprender a proyectar mejor el futuro. Los resultados nos interesan más cuando analizan aspectos esenciales, como la optimización espacial, la interacción cultural entre arquitectura escolar y sociedad, la incidencia en la salud individual y social, etc.

Estoy segura que los artículos aquí reunidos ofrecen un conjunto de referencias válidas. Junto a nuevas reflexiones sobre ejemplos clásicos de gran vigencia, se incorporan algunas nuevas propuestas alternativas tan diversas como las modestas intervenciones de mejoras en algunos patios escolares barceloneses; en el otro extremo las ambiciosas propuestas finlandesas, aun recientes

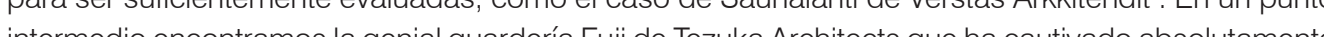
intermedio encontramos la genial guardería Fuji de Tezuka Architects que ha cautivado absolutamente todos, por lo que resulta indiscutible.

Esperaba artículos llegados desde otros campos de conocimiento: la pedagogía, la filosofía, e arte y tantos implicados con la vida, la enseñanza y el proyecto arquitectónico, pero no ha sido asi. Por eso insisto en abrir los ojos y la mente hacia cualquier actividad aprovechable para motivar la tealiviady hacerse unll para el avance hacia una sociedad hejor. Sigue habiendo propuestas ocultas que pasaron desapercibías en su momento o fueron ovidadas y que ahora pueden ser apreuna retros ectiva monográfica sobre la obra de Gerardo Delgado Pérez relevante artista sevillano for Tuve oportunidad de visitar varias veces la exposición titulada "aprendiendo de todas las cosas"; me

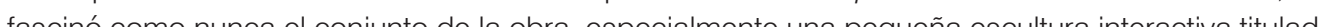
"juvuete per conchita", pieza clave para comprender todo el coniunto y que ah ora acude a mi memoria para confirmar que la arquitectura puede ser plena en un pequeño objeto educativo; cualquier ocasión de reflexión y experimentación contiene un gran potencial para contribuir al futuro. घ 


\section{NUEVOS ESCENARIOS EDUCATIVOS PARA UN NUEVO SIGLO}

\section{Rosa María Añón-Abajas}

p.13 The periods of transition between centuries are usually seeded with restlessness and commotion in the search for new paradigms to revolutionize progress. The questions on contemporanelly and the projects tor a liture society, activate (the The sad reality that surrounds us, affected by diverse political ideologies with opposed objectives, explodes, limiting social progress. The chaos and the uncertainty which has derived from the 20th century, force us to return to the origin, to review the classic melhods, and to try and debale new ones. From the technical, scientific and academic sphere, the efforts concentrate on perfecting the solutions so that they serve all, with the purpose of reducing
differences. Educationalists and architects have been working on it for decades in some cases closely coordinated as that of Hertzberger. Architects thought that architecture had a very important role in life and had much to do. Nows a sick and globalised world has the priority of regenerating nature by interventions that consume very few resources. Primary education must coherently educate in the civic values and attitudes that society needs, and train in basic abilities for that objective. We put creativity forward as an example, a skill that needs to be worked on at the individua

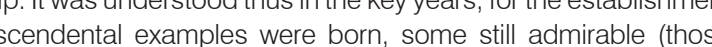
studied here refer to great architects, such as Asplund, Meyer, Scharoun, Lasdun, among others). However, the initiia ideals were diluted, as massification forced simplification of the intense pioneering experiences. The facts incline us to think that hitutions, anitiating a degenerative process It is concluded that it is essential from the first to the outtimate stages of education, to insist on the appreciation of elegant architecture.

p.14 Reading the articles assembled here, we will again meet the questions that motivated the first steps of many architects towards research. It is cheering to verify how much the means at the service of researchers have evolved Every day, more archives and libraries are accessible telematically, networks, databases and open systems favour multitude of studies and theses on school constructions, can be listed in an instant by the most powerfiu weby search engines. It should all affect the quality and clarity of research results. The number of contributions in all spheres has increased so much that the need for some criticism and synthesis has become urgent.

The pioneering accomplishments of the 19th century, evolved in the 20th century in parallel to the historical development of modernity: the initial manifestations of the first third of the century; their revision and normalisation after
World War II: the crisis of the 1970s; and postmodernism. Successively, the models are losing intensity to the extent that opportunities to experiment are reduced immered in standard routines of general application. All movements have an optimistic origin, enthusiastic drive, a pivotal moment and decline. Depressed by negligence, many returned to look to the past to recognize that we were neglecting quality in something as primordial as the educational space. Thus, in the 1980s, many investigations were undertaken on school architecture that began to disseminate at the end of the 1990s, and first years of the present 21 st century, and which are stil continuing to add new contributions, same conclusions as other contemporary or preceding studies, and still more encouraging to find complementary results that are emerging as novel, conclusive and truly propositive. Recognising the time invested by the scientific community, and so much accumliated knowedge on educational architecture, the experimentis governed only by intutition and publications that disclose frivolous, decontextualized images, and devoid of reflection and reasoning, are

es, specifically an not to compete, but to collaborate. Nevertheless, in a society atomized into self-sufficient specialties, obtaining these types of partnerships is more than difficult. There are large global deficiencies, evident not only in underdeveloped whilst arguing that there is no need for new school buildings, because of the negative population orath ind rifes the number of old main empty

p.15 groups has contributed to form a network of physical and digital school museums, presenving and showing the environment of the state school in its dawn and its zenith. The centenaries of important education institutions, elements of the network of school buildings had the same quality level, and with the passage of the thears, even the most emblematic have fallen into obsolescence, having lost their initial brilliance. This reality even affects those areas that we have idealised, such as France and Germany, as affirmed in the article by Anne-Marie Châtelet, the prestigious researcher and professor of Architectural History in several European universitites, and whose publications on school and exemplany comparison of the French and German models in the origin of obligatory education. The particular case of Strasbourg is approached, a border city whose ownership has alternated between both countries throughout its history, which is why its study still continues to be very revealing.

by wars and catastrophes, derived from a society evolved on the basis of that education which promoted a very efficient scientific-technological culture, but also injurious when
it serves a dehumanised consumer society. The problem for architecture and education begins to be serious, and certainly at global level, when multitudes of local institutions are approaching the reclamation and revelation of the orgotten educational heritage, looking insistently into the past to learn to better project the future. The results are more interesting for us when they analyse essential aspects, such as the optimisation of space, the cultural interaction

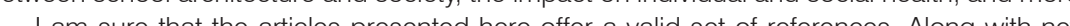

new reflections on classic examples of great validity, some new alternative proposals are incorporated, as diverse as the modest interventions of improvements in some school playgrounds in Barcelona. At the other extreme are the ambitious Finnish proposals, still
too recent to be sufficienty assessed, such as the Saunalahti School by Verstas Arkkitehdit. At an intermediate point. we find the indisputably brilliant Fuji Kindergarten by Tezuka Architects, which has absolutely captivated everyone. Thad hoped for articles from other fields of knowledge: pedagogy, philosophy, art and so many involved with life, mind towards any usable activity to motivate creativity, and to make it useful for the advance towards a better society. There are still hidden proposals that went unnoticed at the time, or were forgotten, and which can now be appreciated in all their dimensions. Last summer, the Andalusian Centre for Contemporary Art held a monographic retrospective on the work of Gerardo Delgado Pérez, an important Sevillian artitst. Trained as an architect, he was Professor at the Higher Technical School of Architecture of "eville. On several occasions, I had the opportunity to visit the exhibitition as never before, especially a small interactive sculpture entitled, "uuquete para conchita" (toy for Conchita). a key piece to understanding the whole, and which now comes to mind to confirm that architecture can be fully found in a small educational object. Any occasion of reflection and experimentation contains great potential to contribute to the future. 